\title{
Cell Surface Determinants Important for Biofilm-Based Solid Substrate Degradation
}

\author{
Jitka Dostálková $^{1 *}$, Vladimír Jirkü ${ }^{1}$, Gita Procházková $^{1}$, Lucie Křiklavová ${ }^{2}$ Tomáš Lederer $^{2}$, \\ Tomáš Brányik ${ }^{1}$ \\ ${ }^{1}$ Institute of Chemical Technology in Prague, Prague, Czech Republic; ${ }^{2}$ Technical University of Liberec, Liberec, Czech Republic. \\ Email: *kyticka.jitka@seznam.cz
}

Received September $11^{\text {th }}, 2013$; revised October $25^{\text {th }}, 2013$; accepted November $26^{\text {th }}, 2013$

Copyright (C) 2013 Jitka Dostálková et al. This is an open access article distributed under the Creative Commons Attribution License, which permits unrestricted use, distribution, and reproduction in any medium, provided the original work is properly cited. In accordance of the Creative Commons Attribution License all Copyrights (C) 2013 are reserved for SCIRP and the owner of the intellectual property Jitka Dostálková et al. All Copyright (C) 2013 are guarded by law and by SCIRP as a guardian.

\begin{abstract}
The study links targeted cell surface characterization to the quantified capacity of cellulose degrading Pseudomonas fluorescens cells to colonize a (similarly characterized) cellulosic carrier. The experiments were conducted to clarify the effect of cultivation conditions on the achieved state of this carrier colonization. The suggested approach seems to be sufficient to verify the right choice of cultivation medium as a major factor determining the binding complementarity between microbial cells and solid cellulose.
\end{abstract}

Keywords: Cellulose Biodegradation; Biofilm Formation; Microbial Cell Adhesion; Pseudomonas fluorescens

\section{Introduction}

Cellulosic wastes represent a solid, persistent substrate due to their cellulose component, which is of heterogeneous structure and insoluble. Nevertheless, bacterial and fungal cellulases are capable of enzymatic hydrolysis resulting in simple saccharides that can be further processed into useful products [1-3].

The $\mathrm{R} \& \mathrm{D}$ in the field of cellulose biodegradation aims now at the cellulose accessibility and the conditioning of continuous enzymatic action at the surface of this insoluble substrate; there is distinguished connection between cellulolytic cell-solid surface binding interaction and hydrolytic action of enzymes $[1,4]$. In other words, the fact that some cellulolytic microorganisms can form cellulolytic biofilms [5-7] may be very useful for technological solubilization of some cellulosic wastes.

Pseudomonas sp. was described as producers of cellulolytic (endo- $\beta$-1,4-D-glucanases, exo- $\beta$-1,4-D-glucanase, $\beta$-1,4-D-glucosidase and/or aryl- $\beta$-glucosidase II) and other enzymes participating on the lignocellulose hydrolysis such as xylanase, cellodextrinase or arabinofuranosidase [8-10]. Unlike fungi (all components of the cellulase complex are released into the culture medium),

${ }^{*}$ Corresponding author. bacteria seem to release only endoglucanases to cultivation media [8]. Capability of the strain Pseudomonas to colonize various substrata/surfaces was proved as well [11-16]; however, there is a lack of information known about cellulose colonization by $P$. fluorescens. Some studies on colonization of cellulosic substrates produced by rumen bacteria have been reported [17-20].

Nevertheless, the process of microbial cell adhesion followed by biofilm formation is very complex, having a profound physiological and physicochemical dependency [5,17,21-26]. In order to predict/control the formation of such cellulose-associated microbial communities, a verified cell marker as well as a method evaluating the colonization of solid cellulose is needed. In this context, the present study links the induced changes in selected physicochemical properties (surface determinants) of the very outer surface of the cellulolytic bacteria Pseudomonas fluorescens with their capability to colonize a model cellulosic carrier (cellophane).

\section{Materials and Methods}

\subsection{Bacterial Strain and Growth Conditions}

Pseudomonas fluorescens, a verified cellulose degrader, was obtained from the collection of microorganisms of 
the Department of Biotechnology (ITC Prague). Cultivations were performed using a rotary shaker $(100 \mathrm{rpm}$, $28^{\circ} \mathrm{C}$ ) and complex medium (further NB): $24 \mathrm{~g} \cdot \mathrm{L}^{-1} \mathrm{nu}-$ trient broth (Roth, Germany), $\mathrm{pH}$ 7.4, or alternatively minimum essential medium (further M5) $\left(\mathrm{g} \cdot \mathrm{L}^{-1}\right.$ distilled water): $0.17 \mathrm{KH}_{2} \mathrm{PO}_{4}, 0.13 \mathrm{~K}_{2} \mathrm{HPO}_{4}, 0.71\left(\mathrm{NH}_{4}\right)_{2} \mathrm{SO}_{4}$, $0.34 \mathrm{MgCl}_{2} \cdot 6 \mathrm{H}_{2} \mathrm{O}, 0.000196 \mathrm{CaCl}_{2}, 0.0006 \mathrm{FeSO}_{4} \cdot 7$ $\mathrm{H}_{2} \mathrm{O}, 0.001 \mathrm{MnCl}_{2} \cdot 4 \mathrm{H}_{2} \mathrm{O}, 0.002 \mathrm{Na}_{2} \mathrm{MoO}_{4} \cdot 2 \mathrm{H}_{2} \mathrm{O}, \mathrm{pH} 6.5$, or on the other hand, a rich bacterial medium (further M1) $\left(\mathrm{g} \cdot \mathrm{L}^{-1} 50 \mathrm{mM}\right.$ phosphate buffer of $\left.\mathrm{pH} 7\right): 5.0$ yeast extract, $1.2\left(\mathrm{NH}_{4}\right) \mathrm{SO}_{4}, 0.5 \mathrm{NaCl}, 0.7 \mathrm{MgCl}_{2} .6 \mathrm{H}_{2} \mathrm{O}, 1.0$ $\mathrm{KH}_{2} \mathrm{PO}_{4}, 0.05 \mathrm{FeCl}_{3} .6 \mathrm{H}_{2} \mathrm{O}, 0.1 \mathrm{CaCl}_{2}$, supplemented with $1 \%(\mathrm{w} / \mathrm{v})$ carboxymethyl cellulose sodium salt (Sigma Aldrich, Czech Republic), omitted in the presence of cellophane. Three types of cellophanes were used: $\mathrm{C} 1$ - covered with nitrocellulose lacquer (Pemar Ltd, Czech Republic); $\mathrm{C} 2-\mathrm{a}$ common wrapping material with a hydrophobic surface (Pas Ltd, Czech Republic); C3-without surface adjustment (Innovia films, USA).

\subsection{X-Ray Photoelectron Spectroscopy Analysis (XPS)}

The pellets of washed cells were resuspended in $2 \mathrm{~mL}$ of cold demineralised water, deposited in a plastic flask and frozen immediately at $-80^{\circ} \mathrm{C}$. The specimens were freeze-dried overnight at $-55^{\circ} \mathrm{C}$ (Heto Power Dry LL3000, Thermo Fisher Scientific, USA). Subsequently, the flasks were stoppered and stored at room temperature in a desiccator. The dehydrated cell powder was gently homogenized with a spatula and analyzed using X-ray photoelectron spectroscopy (ESCAProbeP, Omicron Nanotechnology $\mathrm{GmbH}$, Germany). The cell wall composition was calculated according to [27] and expressed as atomic surface concentration ratios related to total carbon.

\subsection{Contact Angle (CA)}

Cell surfaces for measuring contact angles were prepared by collecting washed $(0.85 \% \mathrm{w} / \mathrm{v} \mathrm{NaCl})$ cells on cellulose nitrate filter (pore size $0.4 \mu \mathrm{m}$, Pragopor, Pragochema Ltd, Czech Republic). The microbial lawns obtained were then deposited on agar plates to stabilize moisture content, fixed to a glass slide and allowed to dry in air for $60 \mathrm{~min}$. The CA was measured using the CAM 200 goniometer (KSV Instruments, Finland) according to [27]. Readings were performed for each liquid at equilibrium stage, i.e. 1 second after the drop was placed on the studied surface [28]. Ten values of CA per sample were measured and results expressed as mean values ( \pm standard deviation). Cellophanes were cut into pieces $(2.5 \times$ $7.5 \mathrm{~cm}$ ), boiled $20 \mathrm{~min}$ in distilled water and subjected to the same CA measurements.

\subsection{Surface Tension/Total Free Energy}

The total surface tension $\left(\gamma_{\text {тот }}\right)$ of the tested solid surfaces and their components $\left(\gamma_{\mathrm{LW}}, \gamma^{+}\right.$and $\left.\gamma^{-}\right)$were calculated from CA by using Young's equation [27]. The values of total free energy of adhesion between solid surfaces in water $\left(\Delta \mathrm{G}_{\mathrm{TOT}}\right)$ were calculated using the thermodynamic approach [29].

\subsection{Microbial Adhesion to Solvents (MATS)}

The adhesion of bacterial cells to solvents was performed and calculated according to [30] using the following pairs of chemicals: chloroform (electron acceptor solvent) and hexadecane (nonpolar solvent), diethyl ether (strong electron donor solvent) and hexane (nonpolar solvent). The cell suspension $(3 \mathrm{~mL})$ was shaken for $1 \mathrm{~min}$. with each solvent $(0.5 \mathrm{~mL})$, respectively, and left to stand $(15$ $\min )$. To express the cell surface properties, the percentage of bound cells was calculated. All values are the mean of three independent determinations $( \pm$ standard deviation).

\subsection{Cell Adhesion Assay}

The cells were harvested in the middle of exponential phase and in the early stationary phase $\left(10 \mathrm{~min}, 4^{\circ} \mathrm{C}\right.$, $10,000 \mathrm{~g}$ ), resuspended in the M1/M5/NB medium and standardized to the optical density of $0.60 \pm 0.01(400$ $\mathrm{nm})$. Sterilized cellophane pieces $(2 \times 3 \mathrm{~cm}, 20 \mathrm{~min}$ boiled in distilled water) were under standard conditions immersed in the preformed cell suspension $(6 \mathrm{~mL})$. Initial cell adhesion to substratum was allowed to occur for $1 \mathrm{~h}$ at $28^{\circ} \mathrm{C}$ on a rotary shaker at $70 \mathrm{rpm}$. The cellophane pieces were gently transferred into $50 \mathrm{~mL}$ of sterile phosphate buffer $\mathrm{pH} 7$ and shaken at $50 \mathrm{rpm}$ for $1 \mathrm{~min}$ in order to remove any loosely attached cells. The cells adhered on the substratum were monitored using phasecontrast microscopy (Eclipse E400, NIKON). Ten images per each substratum (at $40 \times$ objective) were captured randomly (PowerShot A620, Canon) to obtain a representative area covered by cells. Each image was analyzed using the MATLAB 2012 software (The MathWorks, Inc., USA). In order to detect significant discrepancies among results obtained, statistical comparisons were performed using Discriminant Analysis, K-means clustering and Principal Component Analysis (Microsoft Excel 2007, Microsoft, USA). Adhesion assays were performed in triplicate. Furthermore, the obtained data were statistically analyzed with a one-way analysis of variance (ANOVA, MS Excel) and reported as p-values. Differences with p-values of less than 0.05 were considered statistically significant.

\subsection{Biofilm Formation Assay}

Bacterial biofilm formation was observed with time- 
lapse phase-contrast microscopy (Eclipse E400, Nikon), using the FC 81 transmission flow cell (Biosurface Technologies Corporation, USA), inserted cellophane as a transparent carrier, and preformed cell suspension (see 2.6) recycling the cell at a flow rate of $5 \mathrm{~mL} \cdot \mathrm{min}^{-1}$. The viewing window of the cell was divided into three sections (inflow, middle, and outflow). Twenty cellophane surface images were randomly captured in the middle section (PowerShot A620, Canon; software ZoomBrowser EX 5.5) and analysed using the image analysis method according to [31].

\subsection{Biofilm Structure}

In order to extract/quantify structural features from images of biofilms, the MATLAB 2012 software (The MathWorks, Inc., USA) was used for visual evaluation of areal parameters $[30,32,33]$. The parameters are briefly defined in the Results and discussion section; their detailed definitions and calculation procedures are reported by [31].

\section{Results and Discussion}

\subsection{XPS Analysis of $\boldsymbol{P}$. fluorescens Cells}

The elemental composition of the bacterial surface that resulted from integrating $\mathrm{C} 1 \mathrm{~s}, \mathrm{O} 1 \mathrm{~s}, \mathrm{~N} 1 \mathrm{~s}$ peaks from the survey scan spectrum and ratios of $\mathrm{N} / \mathrm{C}, \mathrm{O} / \mathrm{C}$, polysaccharides, proteins and hydrocarbon-like compounds are listed in Table 1.

Carbon is the most abundant surface element in the cells grown in all media and in the exponential and stationary phase. The cell surface nitrogen was detected in the cells cultivated in all media as well. Induced changes in the level of proteins, polysaccharides and hydrocarbon-like compounds are almost uniform and independent on the growth phase with exception medium M1. The data processed through quantitative methodology of Rouxhet et al. [34] show that the surface of the cells cultivated in various media contains 29 - 42 percent of proteins, 32 - 49 percent of polysaccharides and 12 - 43 percent of hydrocarbon-like compounds. The surface of the cells exponentially growing in M1 medium contains more hydrocarbon-like compounds (e.g. lipids) than the cells in stationary phase. This result is in accordance with higher hydrophobicity of the exponentially growing cells.

There is no difference in the cell wall composition between the cells cultivated in NB in the exponential and stationary phase. High content of cell wall polysaccharides is probably related to the fact that $P$. fluorescens produces a great amount of exopolysaccharides [35,36]. On the other hand, the results obtained are in contradiction with Noghabi et al. [37] who established that maximum extracellular biopolymer production occurred in the early stationary growth phase.

\subsection{Physicochemical Properties of Cell and Cellophane Surface}

The impact of media and growth phase on the contact angle changes demonstrates that the lawns of cells grown in a complex (NB) medium show lower (for polar liquids - w, f) and similar (for nonpolar liquids - b) values as compared with cells grown on minimal and less richer M5 and M1 media (Table 2). The effect of the cell population's growth phase on microbial surface properties was in most cases (NB and M5) less apparent compared to the effect of culture media composition. The surface of cells grown in poorer media (M5 and M1) is apparently more hydrophobic than the surface of the cells grown in complex medium (NB) independently of the growth phase. Our results were in accordance with these reported by Jana et al. [38]. Their study demonstrates that hydrophobicity of $P$. fluorescens isolates is influenced by medium constituents and growth conditions which can strongly influence adhesion efficiency, e.g. early to mid-log exponential phase cells were more hydrophobic than stationary phase cells.

Moreover, the cultivation in all three media brings a higher $\gamma^{-}$value (as compared to $\gamma^{+}$), what suggests an electron-donating character of the cell surface. In the majority of media and growth phases tested, the adhesion of $P$. fluorescens cells to solvents (Table 3) was found to be higher to chloroform (electron acceptor) than to

Table 1. XPS atomic ratios for $P$. fluorescens cells.

\begin{tabular}{ccccccccc}
\hline grown in & $\mathrm{O} / \mathrm{C}$ & $\mathrm{N} / \mathrm{C}$ & $\mathrm{C}-(\mathrm{C}, \mathrm{H}) / \mathrm{C}$ & $\mathrm{C}-(\mathrm{O}, \mathrm{N}) / \mathrm{C}$ & $\mathrm{C}=\mathrm{O} / \mathrm{C}$ & $\left(\mathrm{C}_{\mathrm{Pr}} / \mathrm{C}\right)$ & $\left(\mathrm{C}_{\mathrm{Ps}} / \mathrm{C}\right)$ & $\left(\mathrm{C}_{\mathrm{HC}} / \mathrm{C}\right)$ \\
\hline NB exp & 0.41 & 0.11 & 0.75 & 0.24 & 0.002 & 0.40 & 0.34 & 0.26 \\
NB stat & 0.40 & 0.12 & 0.80 & 0.20 & 0.002 & 0.42 & 0.32 & 0.26 \\
M5 exp & 0.34 & 0.10 & 0.45 & 0.12 & 0.01 & 0.35 & 0.27 & 0.39 \\
M5 stat & 0.33 & 0.08 & 0.40 & 0.11 & 0.01 & 0.29 & 0.28 & 0.43 \\
M1 exp & 0.50 & 0.09 & 0.41 & 0.14 & 0.01 & 0.30 & 0.49 & 0.21 \\
M1 stat & 0.52 & 0.12 & 0.41 & 0.14 & 0.01 & 0.42 & 0.46 & 0.12 \\
\hline
\end{tabular}

Proteins $\left(\mathrm{C}_{\mathrm{Pr}} / \mathrm{C}\right)$, polysaccharides $\left(\mathrm{C}_{\mathrm{Ps}} / \mathrm{C}\right)$, hydrocarbon-like compounds $\left(\mathrm{C}_{\mathrm{HC}} / \mathrm{C}\right)$, exp-exponential phase of cell population $($ exp), stationary phase of cell population (stat). 
Table 2. Surface properties of $\boldsymbol{P}$. fluorescens cells collected on cellulose nitrate filter.

\begin{tabular}{ccccccccc}
\hline \multirow{2}{*}{ Grow in } & \multicolumn{3}{c}{ Contact Angle $\left(^{\circ}\right)$} & \multicolumn{5}{c}{ Surface Tension $\left(\mathrm{mJ}^{\circ} \mathrm{m}^{-2}\right)$} \\
\cline { 2 - 9 } & $\mathrm{w}$ & $\mathrm{f}$ & $\mathrm{b}$ & $\gamma^{\mathrm{LW}}$ & $\gamma^{+}$ & $\gamma^{-}$ & $\gamma^{\mathrm{AB}}$ & $\gamma^{\mathrm{TOT}}$ \\
\hline NB exp & $17.3 \pm 0.7$ & $29.3 \pm 1.4$ & $52.9 \pm 0.9$ & 28.5 & 2.2 & 58.9 & 22.7 & 51.2 \\
NB stat & $23.7 \pm 1.4$ & $26.2 \pm 0.8$ & $64.2 \pm 1.8$ & 22.9 & 5.2 & 50.4 & 32.5 & 55.3 \\
M5 exp & $64.9 \pm 3.0$ & $65.6 \pm 2.0$ & $53.9 \pm 1.1$ & 28.0 & 0.0 & 29.4 & 0.5 & 28.6 \\
M5 stat & $56.2 \pm 1.6$ & $59.8 \pm 1.1$ & $59.8 \pm 1.0$ & 25.1 & 0.2 & 37.2 & 5.9 & 31.0 \\
M1 exp & $62.8 \pm 1.8$ & $63.8 \pm 1.6$ & $39.0 \pm 2.2$ & 35.1 & 0.3 & 31.5 & 6.6 & 41.6 \\
M1 stat & $33.0 \pm 1.0$ & $38.8 \pm 1.2$ & $36.6 \pm 1.6$ & 36.1 & 0.3 & 51.8 & 7.3 & 43.3 \\
\hline
\end{tabular}

Table 3. Adhesion of $\boldsymbol{P}$. fluorescens cells to solvents (\%).

\begin{tabular}{ccccc}
\hline Grown in & Diethylether & Hexane & Hexadecane & Chloroform \\
\hline NB exp & $62.3 \pm 6.4$ & $12.2 \pm 0.7$ & $19.1 \pm 10.4$ & $93.7 \pm 7.1$ \\
NB stat & $70.3 \pm 3.2$ & $26.7 \pm 19.8$ & $30.0 \pm 17.4$ & $70.8 \pm 1.9$ \\
M5 exp & $64.1 \pm 2.6$ & $40.6 \pm 1.1$ & $24.8 \pm 3.2$ & $59.8 \pm 2.2$ \\
M5 stat & $23.8 \pm 17.1$ & $23.1 \pm 9.7$ & $19.3 \pm 9.7$ & $41.8 \pm 14.4$ \\
M1 exp & $13.2 \pm 7.7$ & $27.2 \pm 6.9$ & $12.4 \pm 10.0$ & $49.3 \pm 1.5$ \\
M1 stat & $\mathrm{N}$ & $15.7 \pm 11.0$ & $8.9 \pm 5.4$ & $38.6 \pm 10.2$ \\
\hline
\end{tabular}

diethylether (electron donor), what also supports above suggestion $[26,30]$.

Similarly, a generally higher affinity of the cells grown in poorer media (M1 and M5) compared to complex medium (NB) to nonpolar solvents (hexane and hexadecane) shows that the difference between medium composition can result in a manifestation of those surface components that promote cell hydrophobicity. The contact angle values for cellophane surfaces (Table 4) revealed a significantly higher hydrophobicity of the $\mathrm{C} 2$ cellophane. In addition, the values of surface tensions $\left(\gamma^{\text {tot }}\right)$ and their components show that the electron-donor capacity of the C2 cellophane is significantly weaker, as demonstrated by the lowest $\gamma^{-}$value.

In the thermodynamic approach for predicting cell adhesion to solid substrates [39], the values of the total free energy of adhesion between the two studied solid surfaces in water $\left(\Delta \mathrm{G}_{\text {Tот }}\right)$ prompt about the stability of the surface interaction (energetically favorable when $\Delta \mathrm{G}_{\mathrm{TOT}}$ $<0$, unfavorable when $\Delta \mathrm{G}_{\mathrm{TOT}}>0$ ). A favorable (negative) adhesion energy balance was detected for the adhesion of $P$. fluorescens cells to cellophane $\mathrm{C} 2$, in the case of exponential and stationary grown cells in M5 medium $\left(-19.3 \mathrm{~mJ} / \mathrm{m}^{2}\right.$, resp. $\left.-10.2 \mathrm{~mJ} / \mathrm{m}^{2}\right)$ and in $\mathrm{M} 1$ medium $\left(-16.0 \mathrm{~mJ} / \mathrm{m}^{2}\right.$, resp. $\left.-0.9 \mathrm{~mJ} / \mathrm{m}^{2}\right)$. This favorable energy balance was obtained mainly due to the negative balance of polar acid-base interactions $\left(\Delta \mathrm{G}_{\mathrm{AB}}\right)$ between bacteria and cellophane $\mathrm{C} 2$, which can be ascribed to the lowest electron donor $\left(\gamma^{-}\right)$character of C2 (Table 4). Simultaneously, the calculations concerning the two remaining cellophanes ( $\mathrm{C} 1$ and $\mathrm{C} 3)$ resulted in energetically unfavorable balances (Table 5).

\subsection{Cell Adhesion and Biofilm Formation}

From obtained results, there is an apparent influence of growth phase and medium composition effect on $P$. fluorescens cells. Comparing the total free adhesion energies (Table 5) with the results of the adhesion test onto C2 cellophane (Table 6), some deviations between prediction and experiment was found in the case of the most extensively colonized cellophane $\mathrm{C} 2$ (see a less intensive adhesion of the cells grown in M5 medium). For the cell population being in stationary phase and NB medium, there is a significant discrepancy (higher cell adhesion whereas $\Delta \mathrm{G}_{\mathrm{TOT}}$ is positive). In order to explain these disagreements, further experimental results concerning the charges of the interacting surfaces would be necessary. The zeta potentials would allow using the classical colloidal DLVO and extended XDLVO theories for the prediction of the cell adhesion [29]. In contrast to the thermodynamic approach, they are either based on the electrostatic interactions (DLVO) or combine the non-covalent Liftshitz-van der Waals and electrostatic interactions with the Lewis acid-base interactions (XDLVO) [40]. However, it can be concluded that the thermodynamic approach was able to distinguish the general feature of the studied system, namely that the culture medium composition and growth phase can significantly influence cell adhesion.

Subsequent experiments with biofilm formation on cellophane $\mathrm{C} 2$ surface were carried out in order to show in more details the medium effect/growth phase as well as possible different intensity of later biofilm detachment activity (Figure 1). 
Table 4. Surface properties of cellophane.

\begin{tabular}{cccccccccc}
\hline \multirow{2}{*}{ Cellophane } & \multicolumn{3}{c}{ Contact Angle $\left(^{\circ}\right)$} & \multicolumn{4}{c}{ Surface Tension $\left(\mathrm{mJ} \cdot \mathrm{m}^{-2}\right)$} \\
\cline { 2 - 9 } & $\mathrm{w}$ & $\mathrm{f}$ & $\mathrm{b}$ & $\gamma^{\mathrm{LW}}$ & $\gamma^{+}$ & $\gamma^{-}$ & $\gamma^{\mathrm{AB}}$ & $\gamma^{\mathrm{TOT}}$ \\
\hline $\mathrm{C} 1$ & $44.1 \pm 2.4$ & $47.5 \pm 2.2$ & $46.4 \pm 2.6$ & 31.7 & 0.3 & 44.2 & 7.1 & 38.8 \\
$\mathrm{C} 2$ & $88.2 \pm 4.3$ & $78.7 \pm 2.4$ & $50.9 \pm 1.0$ & 29.5 & 0.4 & 9.1 & 3.7 & 33.2 \\
$\mathrm{C} 3$ & $36.9 \pm 3.4$ & $30.3 \pm 5.2$ & $35.2 \pm 4.1$ & 36.7 & 1.1 & 39.9 & 13.4 & 50.0 \\
\hline
\end{tabular}

$\mathrm{w}$-water, $\mathrm{f}$ - formamide, $\mathrm{b}$ - 1 -bromonaphthalene.

Table 5. Free energy of interaction $\left(\Delta \mathrm{G}_{\mathrm{TOT}}\right)$ and its components $\left(\Delta \mathrm{G}_{\mathrm{LW}}, \Delta \mathrm{G}_{\mathrm{AB}}\right)$ between $P$. fluorescens cells and cellophanes $(\mathrm{C} 1, \mathrm{C} 2, \mathrm{C} 3)$ in water (cell-water-support) at the separation distance of $0.158 \mathrm{~nm}$ calculated according to the thermodynamic approach.

\begin{tabular}{|c|c|c|c|c|c|c|c|c|c|}
\hline \multirow{3}{*}{ Grown in } & \multicolumn{9}{|c|}{ Free Energy of Interaction $\left(\mathrm{mJ} / \mathrm{m}^{2}\right)$} \\
\hline & \multicolumn{3}{|c|}{$\mathrm{C} 1$} & \multicolumn{4}{|c|}{$\mathrm{C} 2$} & \multicolumn{2}{|c|}{$\mathrm{C} 3$} \\
\hline & $\Delta \mathrm{G}_{\mathrm{LW}}$ & $\Delta \mathrm{G}_{\mathrm{AB}}$ & $\Delta \mathrm{G}_{\mathrm{TOT}}$ & $\Delta \mathrm{G}_{\mathrm{LW}}$ & $\Delta \mathrm{G}_{\mathrm{AB}}$ & $\Delta \mathrm{G}_{\mathrm{TOT}}$ & $\Delta \mathrm{G}_{\mathrm{LW}}$ & $\Delta \mathrm{G}_{\mathrm{AB}}$ & $\Delta \mathrm{G}_{\mathrm{TOT}}$ \\
\hline NB exp & -1.3 & 35.1 & 33.8 & -1.1 & 10.2 & 9.1 & -1.9 & 30.0 & 28.2 \\
\hline NB stac & -0.2 & 27.3 & 27.1 & -0.2 & 8.1 & 7.9 & -0.3 & 23.4 & 23.1 \\
\hline M5 exp & -1.2 & 19.3 & 18.1 & -1.0 & -18.3 & -19.3 & -1.7 & 15.6 & 13.9 \\
\hline M5 stac & -0.7 & 24.1 & 23.4 & -0.5 & -9.6 & -10.2 & -0.9 & 20.0 & 19.0 \\
\hline M1 exp & -2.4 & 19.4 & 17.0 & -2.0 & -14.0 & -16.0 & -3.5 & 15.8 & 12.4 \\
\hline M1 stac & -2.6 & 33.9 & 31.3 & -2.2 & 1.2 & -0.9 & -3.7 & 28.7 & 25.0 \\
\hline
\end{tabular}

exp — exponential phase of cell population, stat — stationary phase of cell population, $\mathrm{C} 1$ - C3 — cellophane type 1 - 3 .

Table 6. Surface coverage (\%) with $P$. fluorescens cells on C2 surface.

\begin{tabular}{cc}
\hline Medium-Growth Phase & Colonized Surface (\%) \\
\hline NB-exp & $0.70 \pm 0.16$ \\
NB-stat & $15.9 \pm 0.57$ \\
M1-exp & $11.3 \pm 0.92$ \\
M1-stat & $3.91 \pm 0.21$ \\
M5-exp & $0.42 \pm 0.03$ \\
M5-stat & $0.43 \pm 0.02$
\end{tabular}

exp - exponential phase of cell population, stat—stationary phase of cell population.

The cells grown in two completely different media (rich/poor, resp. NB and M5) were chosen for biofilm formation assay (Figures 1 and 2). The observed drop in the cellophane $(\mathrm{C} 2)$ surface coverage can be explained by biofilm sloughing, i.e. a random biomass detachment attributed to nutrient/oxygen depletion deep within biofilms [41]. In the Figures 1 and 2, there is demonstrated a significant effect of chosen media and a difference in the extent of colonization between both growth phases in dynamic conditions.

\subsection{Biofilm Structure}

The variability of biofilm structure was characterized by a change in these areal parameters: areal porosity (the ratio of void area to total area); diffusion distance (the

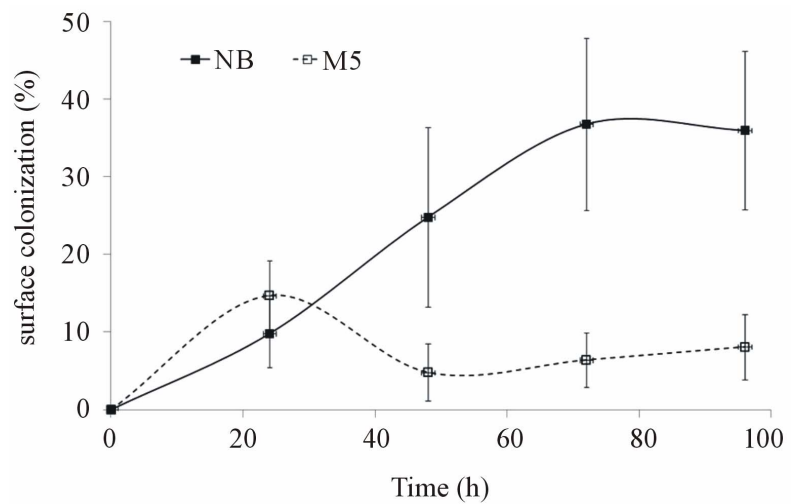

Figure 1. Time course of $P$. fluorescens biofilm formation on cellophane C2 surface (biofilm formation assay; medium: M5, NB)—exponential phase.

minimum distance from the cells in the cluster to interstitial space); run length (the vertical/horizontal dimension of a cell cluster) [31-33,42]. Results are summarized as the effect of media and growth phase on time course of changes in the values of the respective parameters, calculated from the images of the biofilm colonizing cellophane $\mathrm{C} 2$, and except for areal porosity expressed as a number of pixels (Tables 7-10).

At the beginning of biofilm formation, the areal porosity was high and there was a small number of cell clusters with uneven distribution attached to the cellophane surface. As biofilm matures, the cell clusters grew and the areal porosity decreases. Lower porosity indicates 
higher coverage of the cellophane $\mathrm{C} 2$ surface. As shown in the Tables 7-10, the porosity of biofilms formed in NB and M5 medium decreased (after 3 days) to about 60 and 90 percent, what may be attributed to about 40 and 10 percent surface coverage, respectively. The sloughing of biofilm grown in almost all studied cases can be observed also on the increased areal porosity after 4 days (Tables 7-10). The NB medium (especially in exponential growth phase) evidently supports a higher biofilm growth rate, i.e. the growth of respective, attached cell clusters. In this connection, the next parameters (average/maximum diffusion distance) show the changes in their average and maximum diameters. The average diffusion distance reflects the average size of the cell clusters (in these biofilms almost round-shaped). As time progresses, the values of the average diffusion distance slightly oscillated, but not uniformly for both media/ growth phases. The cell cluster sizes differentiate because old clusters grow larger and new ones arise. On the other hand, the maximum diffusion distance values of biofilms grown in NB and M5 increased with time and their maximum values were different. The growth of re- spective cell clusters in NB medium was significantly slower. Similarly to the values of average diffusion distance parameter, the values of horizontal and vertical run-length also oscillate. In both media/growth phases horizontal run lengths reach higher values, suggesting that formed biofilms are oriented more horizontally (medium flow effect) [43].

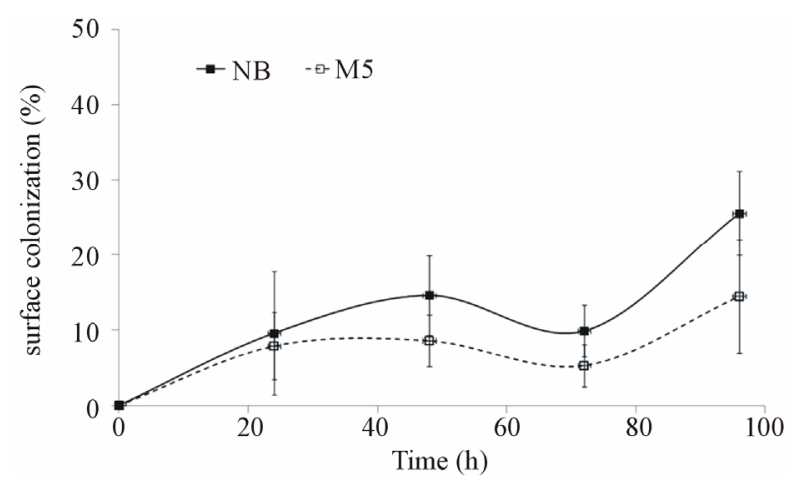

Figure 2. Time course of $P$. fluorescens biofilm formation on cellophane C2 surface (biofilm formation assay; medium: M5, NB)—stationary phase.

Table 7. Time course of changes in areal parameters for biofilms formed on cellophane C2 surface in medium NBexponential phase.

\begin{tabular}{cccccc}
\hline Parameter/time (h) & 4 & 24 & 48 & 72 & 96 \\
\hline Areal porosity (\%) & $90.2 \pm 4.4$ & $75.2 \pm 11.6$ & $63.2 \pm 11.1$ & $64.0 \pm 10.2$ & $90.2 \pm 4.4$ \\
Maximum diffusion distance & $175 \pm 92.8$ & $326 \pm 138$ & $454 \pm 182$ & $296 \pm 121$ & $175 \pm 92.8$ \\
Average diffusion distance & $10.1 \pm 3.4$ & $6.6 \pm 1.8$ & $5.2 \pm 4.1$ & $3.7 \pm 0.8$ & $10.1 \pm 3.4$ \\
Horizontal run length & $22.0 \pm 7.0$ & $15.5 \pm 3.6$ & $12.2 \pm 6.7$ & $11.1 \pm 2.3$ & $22.0 \pm 7.0$ \\
Vertical run length & $20.6 \pm 6.9$ & $13.4 \pm 3.4$ & $11.7 \pm 9.8$ & $9.4 \pm 1.9$ & $20.6 \pm 6.9$ \\
\hline
\end{tabular}

\pm Standard deviations show biofilm heterogeneity.

Table 8. Time course of changes in areal parameters for biofilms formed on cellophane C2 surface in medium NB-stationary phase.

\begin{tabular}{cccccc}
\hline Parameter/time (h) & 4 & 24 & 48 & 72 & 96 \\
\hline Areal porosity (\%) & $90.4 \pm 8.2$ & $85.4 \pm 5.3$ & $90.1 \pm 3.4$ & $74.4 \pm 5.6$ & $90.4 \pm 8.2$ \\
Maximum diffusion distance & $108 \pm 35.5$ & $219 \pm 120$ & $108 \pm 47.6$ & $281 \pm 91.0$ & $108 \pm 35.5$ \\
Average diffusion distance & $3.9 \pm 0.6$ & $9.1 \pm 1.4$ & $7.5 \pm 2.2$ & $7.9 \pm 2.9$ & $3.9 \pm 0.6$ \\
Horizontal run length & $10.0 \pm 1.4$ & $20.6 \pm 2.5$ & $16.9 \pm 4.1$ & $18.3 \pm 5.1$ & $10.0 \pm 1.4$ \\
Vertical run length & $8.5 \pm 1.3$ & $18.2 \pm 2.5$ & $15.2 \pm 4.3$ & $15.6 \pm 4.9$ & $8.5 \pm 1.3$ \\
\hline
\end{tabular}

\pm Standard deviations show biofilm heterogeneity.

Table 9. Time course of changes in areal parameters for biofilms formed on cellophane C2 surface in medium BSMexponential phase.

\begin{tabular}{|c|c|c|c|c|c|}
\hline Parameter/time (h) & 4 & 24 & 48 & 72 & 96 \\
\hline Areal porosity (\%) & $85.3 \pm 4.5$ & $95.2 \pm 3.7$ & $93.6 \pm 3.5$ & $91.9 \pm 4.2$ & $85.3 \pm 4.5$ \\
\hline Maximum diffusion distance & $148 \pm 88.6$ & $64.5 \pm 37.4$ & $81.9 \pm 21.0$ & $95.3 \pm 33.9$ & $148 \pm 88.6$ \\
\hline Average diffusion distance & $4.9 \pm 0.6$ & $4.1 \pm 1.0$ & $4.7 \pm 0.6$ & $4.5 \pm 0.8$ & $4.9 \pm 0.6$ \\
\hline Horizontal run length & $11.7 \pm 0.6$ & $9.7 \pm 2.1$ & $10.6 \pm 1.3$ & $11.2 \pm 1.7$ & $11.7 \pm 0.6$ \\
\hline Vertical run length & $9.4 \pm 1.1$ & $8.8 \pm 2.1$ & $9.2 \pm 1.2$ & $9.0 \pm 1.9$ & $9.4 \pm 1.1$ \\
\hline
\end{tabular}

\pm Standard deviations show biofilm heterogeneity. 
Table 10. Time course of changes in areal parameters for biofilms formed on cellophane C2 surface in medium BSM-stationary phase.

\begin{tabular}{|c|c|c|c|c|c|}
\hline Parameter/time (h) & 4 & 24 & 48 & 72 & 96 \\
\hline Areal porosity (\%) & $92.1 \pm 4.5$ & $91.4 \pm 3.4$ & $94.7 \pm 2.8$ & $85.5 \pm 7.6$ & $92.1 \pm 4.5$ \\
\hline Maximum diffusion distance & $159 \pm 113$ & $116 \pm 43.1$ & $96.0 \pm 47.9$ & $84.0 \pm 22.2$ & $159 \pm 113$ \\
\hline Average diffusion distance & $5.6 \pm 4.3$ & $5.2 \pm 0.7$ & $7.2 \pm 0.9$ & $7.4 \pm 1.0$ & $5.6 \pm 4.3$ \\
\hline Horizontal run length & $11.7 \pm 0.6$ & $11.5 \pm 1.4$ & $14.9 \pm 1.9$ & $16.3 \pm 2.4$ & $11.7 \pm 0.6$ \\
\hline
\end{tabular}

\pm Standard deviations show biofilm heterogeneity.

Nevertheless, comparing the changes in the value profile of those 4 areal parameters, we see again a stimulating effect of NB medium. In a view of the findings that the production of both soluble and cell-associated cellulases is increased in response to low $\mathrm{N}$ availability, and $\mathrm{N}$-limited biofilms bind strongly to cellulose surfaces $[7,44]$, it should be pointed out that the NB medium, found as more stimulating, is a strong source of nitrogen.

However, we must realize that hydrodynamic effects and other factors affecting surface attached growth (a strong biofilm former is not always a strong biodegrader and contrariwise) can also play a crucial role in the formation and function of "our" biofilm. Moreover, cellulolytic microorganisms can establish synergistic relationships with non-cellulolytic species in cellulosic wastes, particularly those generated at health care or food processing facilities. Therefore, the choice of medium based on above approach should serve only as a starting, but fundamental point of cell culture preparation, if a biofilm application is intended for the pretreatment/conversion of cellulosic materials.

\section{Conclusion}

Bacterial biofilm as a form of the multicellularity of single cell organisms is commonly referred to as the biofilm mode of growth, as opposed to the growth of free-floating cells in the culture medium (planktonic lifestyle). In this context, the biofilm of a cellulolytic microorganism, if applied as a living, multicellular biodegrader of cellulosic materials, is expected to offer sustainability, selfrepair, stable functional performance and multipoint administration of required degradative function. Nevertheless, the conditions of intensive and reproducible biofilm formation must be always detected and secured. The described approach was found suitable to detect which medium stimulates reproducibly the enhancement of cell surface hydrophobicity, electron-donor capacity and favorable (cell-carrier) adhesion energy, which are properties always somehow determining the intensity of microbial colonization of a solid cellulose. The same approach enables us to characterize the surface of this carrier, and confront the complementarity of cell/carrier surfaces through cell adhesion and biofilm structure assays.

\section{Acknowledgements}

The authors acknowledge the financial support of MEYS, Czech Republic, through the projects: Eureka E!3654Euroenviron Biopols, and the Project OP VaVpI Centre for Nanomaterials, Advanced Technologies and Innovation CZ.1.05/2.1.00/01.0005, as well as of the Grant Agency of the Czech Republic (project GACR P503/ 12/1424).

\section{REFERENCES}

[1] L. R. Lynd, P. J. Weimer, W. H. Zyl and I. S. Pretorius, "Microbial Cellulose Utilization: Fundamentals and Biotechnology," Microbiology and Molecular Biology Reviews, Vol. 66, No. 3, 2002, pp. 506-577.

http://dx.doi.org/10.1128/MMBR.66.4.739.2002 http://dx.doi.org/10.1128/MMBR.66.3.506-577.2002

[2] M. Wenzel, I. Schonig, M. Berchtold, P. Kampfer and H. Konig, "Aerobic and Facultatively Anaerobic Cellulolytic Bacteria form the Gut of the Termite Zootermopsis angusticollis," Journal of Applied Microbiology, Vol. 92, No. 1, 2002, pp. 32-40. http://dx.doi.org/10.1046/j.1365-2672.2002.01502.x

[3] Z. Shi, G. Luo and G. Wang, "Cellulomonas carbonis sp. nov., Isolated from Coal Mine Soil," International Journal of Systematic and Evolutionary Microbiology, Vol. 62, No. P8, 2012, pp. 2004-2010. http://dx.doi.org/10.1099/ijs.0.034934-0

[4] W. Schwarz, "The Cellulosome and Cellulose Degradation by Anaerobic Bacteria," Applied Microbiology and Biotechnology, Vol. 56, No. 5-6, 2001, pp. 634-649. http://dx.doi.org/10.1007/s002530100710

[5] A. N. Alonso, P. J. Pomposiello and S. B. Leschine. "Biofilm Formation in the Life Cycle of the Cellulolytic Actinomycete Thermobifida fusca," Biofilms, 2008, pp. 1-11. http://dx.doi.org/10.1017/S1479050508002238

[6] Z. Wang and S. Chen, "Potential of Biofilm-Based Biofuel Production," Applied Microbiology and Biotechnology, Vol. 83, No. 1, 2009, pp. 1-18. http://dx.doi.org/10.1007/s00253-009-1940-9

[7] J. M. Young, S. B. Leschine and G. Reguera, "Reversible Control of Biofilm formation by Cellulomonas spp. in 
Response to Nitrogen Availability," Environmental Microbiology, Vol. 14, No. 3, 2012, pp. 594-604. http://dx.doi.org/10.1111/j.1462-2920.2011.02596.x

[8] K. Ramasamy and H. Verachtert, "Localization of Cellulase Components in Pseudomonas sp. Isolated from Activated Sludge," Microbiology, Vol. 117, No. 1, 1980, pp. 181-191. http://dx.doi.org/10.1099/00221287-117-1-181

[9] M. A. Luis, L. M. A. Ferreira, T. M. Wood, G. Williamson, C. Faulds, G. P. Hazlewood, G. W. Black and H. J. Gilbert, "A Modular Esterase from Pseudomonas fluorescens subsp. cellulosa Contains a Non-Catalytic Cellulose-Binding Domain," The Biochemical Journal, Vol. 294, Pt. 2, 1993, pp. 349-355.

[10] C. L. Cheng and J. S. Chang, "Hydrolysis of Lignocellulosic Feedstock by Novel Cellulases Originating from Pseudomonas sp. CL3 for Fermentative Hydrogen Production," Bioresource Technology, Vol. 102, No. 18, 2011, pp. 8628-8634.

http://dx.doi.org/10.1016/j.biortech.2011.03.053

[11] M. Fletcher, "Attachment of Pseudomonas fluorescens to Glass and Influence of Electrolytes on Bacterium-Substratum Separation Distances," Journal of Bacteriology, Vol. 170, No. 5, 1988, pp. 2027-2030.

[12] B. Song and L. G. Leff, "Influence of Magnesium Ions on Biofilm Formation by Pseudomonas fluorescens," Microbiological Research, Vol. 161, No. 4, 2006, pp. 355-361. http://dx.doi.org/10.1016/j.micres.2006.01.004

[13] J. Kives, B. Orgaz and C. SanJosé, "Polysaccharide Differences between Planktonic and Biofilm-Associated EPS from Pseudomonas fluorescens B52," Colloids and Surfaces B: Biointerfaces, Vol. 52, No. 2, 2006, pp. 123-127. http://dx.doi.org/10.1016/j.colsurfb.2006.04.018

[14] D. Nercessian, F. B. Duville, M. Desimone, S. Simison and J. B. Busalmen, "Metabolic Turnover and Catalase Activity of Biofilms of Pseudomonas fluorescens (ATCC 17552) as Related to Copper Corrosion," Water Research, Vol. 44, No. 8, 2010, pp. 2592-2600. http://dx.doi.org/10.1016/j.watres.2010.01.014

[15] I. E. Ivanov, C. D. Boyd, P. D. Newell, M. E. Schwartz, L. Turnbull, M. S. Johnson, C. B. Whitchurch, G. A. O'Toole and T. A. Camesano, "Atomic Force and Super-Resolution Microscopy Support a Role for LapA as a Cell-Surface Biofilm Adhesin of Pseudomonas fluorescens," Research in Microbiology, Vol. 163, No. 9-10, 2012, pp. 685-691. http://dx.doi.org/10.1016/j.resmic.2012.10.001

[16] R. Djeribi, W. Bouchloukh, T. Jouenne and B. Menaa, "Characterization of Bacterial Biofilms Formed on Urinary Catheters," American Journal of Infection Control, Vol. 40, No. 9, 2012, pp. 854-959.

http://dx.doi.org/10.1016/j.ajic.2011.10.009

[17] C. O'Sullivan, P. C. Burrell, M. Pasmore, W. P. Clarke and L. L. Blackall, "Application of Flowcell Technology for Monitoring Biofilm Development and Cellulose Degradation in Leachate and Rumen Systems," Bioresource Technology, Vol. 100, No. 1, 2009, pp. 492-496. http://dx.doi.org/10.1016/j.biortech.2008.06.028

[18] A. Dumitrache, G. Wolfaardt, G. Allen, S. N. Liss and L. R. Lynd, "Form and Function of Clostridium thermocellum Biofilms," Applied and Environmental Microbiology,
Vol. 79, No. 1, 2013, pp. 231-239.

http://dx.doi.org/10.1128/AEM.02563-12

[19] Z. W. Wang, S. H. Lee, J. Elkins and J. Morrell-Falvey, "Spatial and Temporal Dynamics of Cellulose Degradation and Biofilm Formation by Caldicellulosiruptor obsidiansis and Clostridium thermocellum," AMB Express, Vol. 1, No. 1, 2011, p. 30. http://dx.doi.org/10.1186/2191-0855-1-30

[20] Z. W. Wang, S. H. Lee, J. G. Elkins, Y. Li, S. HamiltonBrehm and J. L. Morrell-Falvey, "Continuous Live Cell Imaging of Cellulose Attachment by Microbes under Anaerobic and Thermophilic Conditions Using Confocal Microscopy," Journal of Environmental Sciences, Vol. 25, No. 5, 2013, pp. 849-856. http://dx.doi.org/10.1016/S1001-0742(12)60104-1

[21] D. Cunliffe, C. Smart, C. Alexander and E. Vulfson, "Bacterial Adhesion at Synthetic Surfaces," Applied Environment Microbiology, Vol. 65, No. 11, 1999, pp. 49955002.

[22] N. Mohamed, M. Teeters, J. Patti, M. Hook and J. Ross, "Inhibition of Staphylococcus aureus Adherence to Collagen under Dynamic Conditions," Infection and Immunity, Vol. 67, No. 2, 1999, pp. 589-594.

[23] G. Bruinsma, H. C. van der Mei and H. J. Bussher, "Bacterial Adhesion to Surface Hydrophilic and Hydrophobic Contact Lenses," Biomaterials, Vol. 22, No. 24, 2001, pp. 3217-3224. http://dx.doi.org/10.1016/S0142-9612(01)00159-4

[24] W. Dunne, "Bacterial Adhesion: Seen Any Good Biofilms Lately?" Clinical Microbiology Reviews, Vol. 15, No. 2, 2003, pp. 155-166. http://dx.doi.org/10.1128/CMR.15.2.155-166.2002

[25] N. Cerca, G. B. Pier, M. Vilanova, R. Oliveira and J. Azeredo, "Quantitative Analysis of Adhesion and Biofilm Formation on Hydrophilic and Hydrophobic Surfaces of Clinical Isolates of Staphylococcus epidermidis," Research in Microbiology, Vol. 156, No. 4, 2005, pp. 506514. http://dx.doi.org/10.1016/j.resmic.2005.01.007

[26] F. Hamadi and H. Latrache, "Comparison of Contact Angle Measurement and Microbial Adhesion to Solvents for Assaying Electron Donor-Electron Acceptor (AcidBase) Properties of Bacterial Surface," Colloids and Surfaces B: Biointerfaces, Vol. 65, No. 1, 2008, pp. 134-139. http://dx.doi.org/10.1016/j.colsurfb.2008.03.010

[27] M. Kurec and T. Brányik, "The Role of Physicochemical Interactions and FLO Genes Expression in the Immobilization of Industrially Important Yeasts by Adhesion," Colloids and Surfaces B: Biointerfaces, Vol. 84, No. 2, 2011, pp. 491-497.

http://dx.doi.org/10.1016/j.colsurfb.2011.02.004

[28] P. K. Sharma and H. K. Rao, "Analysis of Different Approaches for Evaluation of Surface Energy of Microbial Cells by Contact Angle Goniometry," Advances in Colloid and Interface Science, Vol. 98, No. 3, 2002, pp. 341463. http://dx.doi.org/10.1016/S0001-8686(02)00004-0

[29] C. J. Oss, "Hydrophobicity of Biosurfaces - Origin, Quantitative Determination and Interaction Energies," Colloids and Surfaces B: Biointerfaces, Vol. 5, No. 3-4, 1995, pp. 91-110. http://dx.doi.org/10.1016/0927-7765(95)01217-7 
[30] M. N. Bellon-Fontaine, J. Rault and C. J. van Oss, "Microbial Adhesion to Solvents: A Novel Method to Determine the Electron-Donor/Electron-Acceptor or Lewis Acid-Base Properties of Microbial Cells," Colloids and Surfaces B: Biointerfaces, Vol. 7, No. 1-2, 1996, pp. 4753. http://dx.doi.org/10.1016/0927-7765(96)01272-6

[31] X. Yang, H. Beyenal, G. Harkin and Z. Lewandowski, "Quantifying Biofilm Structure Using Image Analysis," Journal of Microbiological Methods, Vol. 39, No. 2, 2000, pp. 109-119. http://dx.doi.org/10.1016/S0167-7012(99)00097-4

[32] H. Beyenal, C. Donovan, Z. Lewandowski and G. Harkin, "Three-Dimensional Biofilm Structure Quantification," Journal of Microbiological Methods, Vol. 59, No. 3, 2004, pp. 395-413. http://dx.doi.org/10.1016/j.mimet.2004.08.003

[33] Z. Lewandowski and H. Beyenal, "Fundamentals of Biofilm Research," CRC Press, Boca Raton, 2007.

[34] P. G. Rouxhet, N. Mozes, P. B. Dengis, Y. F. Dufrêne, P. A. Gerin and M. J. Genet, "Application of X-Ray Photoelectron Spectroscopy to Microorganisms," Colloids and Surfaces B: Biointerfaces, Vol. 2, No. 1-3, 1994, pp. 347369. http://dx.doi.org/10.1016/0927-7765(94)80049-9

[35] S. F. Osman, W. F. Fett, P. Irwin, P. Cescutti, J. N. Brouillette and J. V. O'Connor, "The Structure of the Exopolysaccharide of Pseudomonas fluorescens Strain H13," Carbohydrate Research, Vol. 300, No. 4, 1997, pp. 323-327. http://dx.doi.org/10.1016/S0008-6215(97)00069-4

[36] C. C. Hung, P. H. Santschi and J. B. Gillow, "Isolation and Characterization of Extracellular Polysaccharides Produced by Pseudomonas fluorescens Biovar II," Carbohydrate Polymers, Vol. 61, No. 2, 2005, pp. 141-147. http://dx.doi.org/10.1016/j.carbpol.2005.04.008

[37] K. A. Noghabi, H. S. Zahiri and S. C. Yoon, "The Production of a Cold-Induced Extracellular Biopolymer by Pseudomonas fluorescens BM07 under Various Growth Conditions and Its Role in Heavy Metals Absorption," Process Biochemistry, Vol. 42, No. 5, 2007, pp. 847-855. http://dx.doi.org/10.1016/j.procbio.2007.02.004

[38] T. K. Jana, A. K. Srivastava, K. Csery and D. K. Arora, "Influence of Growth and Environmental Conditions on Cell Surface Hydrophobicity of Pseudomonas fluorescens in Non-Specific Adhesion," Canadian Journal of Microbiology, Vol. 46, No. 1, 2000, pp. 28-37.

http://dx.doi.org/10.1139/w99-104

[39] R. Bos, H. C. van der Mei and H. J. Busscher, "PhysicoChemistry of Initial Microbial Adhesive Interactions-Its Mechanisms and Methods for Study," FEMS Microbiology Reviews, Vol. 23, No. 2, 1999, pp. 179-230. http://dx.doi.org/10.1111/j.1574-6976.1999.tb00396.x

[40] C. J. Oss, "Long-Range and Short-Range Mechanisms of Hydrophobic Attraction and Hydrophilic Repulsion in Specific and Aspecific Interactions," Journal of Molecular Recognition, Vol. 16, No. 4, 2003, pp. 177-190. http://dx.doi.org/10.1002/jmr.618

[41] M. C. M. Loosdrecht, J. J. Heijnen, H. Eberl, J. Kreft and C. Picioreanu, "Mathematical Modelling of Biofilm Structures," Antonie van Leeuwenhoek, Vol. 81, No. 1-4, 2002, pp. 245-256. http://dx.doi.org/10.1023/A:1020527020464

[42] G. Jackson, H. Beyenal, W. M. Rees and Z. Lewandowski, "Growing Reproducible Biofilms with Respect to Structure and Viable Cell Counts," Journal of Microbiological Methods, Vol. 47, No. 1, 2001, pp. 1-10. http://dx.doi.org/10.1016/S0167-7012(01)00280-9

[43] Y. Liu and J.-H. Tay, "The Essential Role of Hydrodynamic Shear Force in the Formation of Biofilm and Granular Sludge," Journal of Microbiological Methods, Vol. 36, No. 7, 2002, pp. 1653-1665. http://dx.doi.org/10.1016/S0043-1354(01)00379-7

[44] Y. Lu, Y. H. Zhang and L. R. Lynd, "Enzyme-Microbe Synergy during Cellulose Hydrolysis by Clostridium thermocellum," Proceedings of the National Academy of Sciences of the United States of America, Vol. 103, No. 44, 2006, pp. 16165-16169. http://dx.doi.org/10.1073/pnas.0605381103 